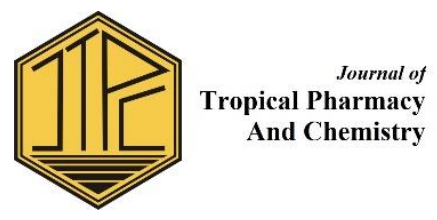

\title{
a-GLUCOSIDASE INHIBITORY ACTIVITY OF IN VITRO COMBINATION OF 96\% ETHANOLIC EXTRACT OF BROTOWALI STEM (Tinospora cordifolia) AND CASHEW APPLE (Anacardium occidentale L.)
}

\section{Wanudya Atmajani*, Ahya Nafila Fatihati, Afifah Mujahidah Shalihah, Ika Trisharyanti Dian Kusumowati}

Faculty of Pharmacy of Muhammadiyah University of Surakarta

*Corresponding author email: k100150049@student.ums.ac.id

\begin{abstract}
Cashew tree (Anacardium occidentale L), contains flavonoid compound which plays a role in the medical treatment of Diabetes Mellitus because this compound has activity as an $\alpha$ glucosidase inhibitor. Brotowali stem extract (Tinospora cordfolia) demonstrated $\alpha$ glucosidase inhibitory (AGIS) activity. This research aimed to measure 96\% ethanolic extract AGIS activity of brotowali-cashew apple combination (BJM). The research was conducted by using ELISA reader instrument at $405 \mathrm{~nm}$ for AGIS activity test. The $\mathrm{IC}_{50}$ was calculated from each sample. The $\mathrm{IC}_{50}$ of brotowali stem and cashew apple was $34,61 \mu \mathrm{g} / \mathrm{ml}$ and $109,32 \mu \mathrm{g} / \mathrm{ml}$. Then, the combination of brotowali and cashew apple extract was mixed with each concentration of $0,5 \%$. From 1:0, 1:2, 1:1, 2:1, and 0:1 BJM comparison resulted in AGIS power percentage averages of $84.05 \%, 69.51 \%, 70.92 \%, 68.10 \%, 40.37 \%$. The results of this research indicated that brotowali stem has the potential as AGIS, while cashew apple has not any potential towards AGIS and that extract combination does not give synergic effect. Therefore, the use of a combination of brotowali-cashew apple extract is not as effective as the use of brotowali single extracts to inhibit the $\alpha$-glucosidase enzyme
\end{abstract}

Keywords: Anacardium occidentale L, Tinospora cordifolia, $\alpha$-glucosidase enzyme, combination, inhibition

\section{Submitted on: 09 September $2018 \quad$ Accepted on: 27 December 2018}

DOI: https://doi.org/10.25026/jtpc.v4i4.198

\section{INTRODUCTION}

Diabetes mellitus is a chronic disease which causes the pancreas to does not produce insulin normally or not unable to use insulin effectively so that it results in an increase of sugar in the blood. The number of diabetes cases is increasing year by year [1]. One of pharmacological therapy for diabetes can be performed by administration oral hypoglycemic drugs which are by delaying absorption in the gastrointestinal tract so that it can control postprandial hyperglycemia in patients with type 2 diabetes [2].

The control of the amount of glucose absorbed into the bloodstream can 
be performed by inhibiting the $\alpha$ glucosidase enzyme to reduce hyperglycemia [3]. $\alpha$-glucosidase enzymes work to hydrolyze carbohydrates in food into molecules that can be absorbed by the intestine, and these $\alpha$-glucosidase inhibitors work competitively in inhibiting the work of enzymes that break down glucose and sucrose [4]. $\alpha$-glucosidase inhibitors are a medical treatment which is effective, safe and can be tolerated by patients with diabetes [2].

Brotowali (Tinospora cordifolia) is one of the traditional plants which is commonly used as antidiabetic therapy in India and has been shown to have antihyperglycemic activity [5]. Previous research has reported that Brotowali stem extracts showed in vitro and in vivo activities of $\alpha$-glucosidase inhibitors [6]. Research by Hamid et al. (2015) showed that brotowali has potent components that inhibit $\alpha$-glucosidase, namely borapetoside C, 4-hydroxybenzaldehyde, lysicamine and liriodenine alkaloids [7].

Cashew apple (Anacardium occidentale $L$.) is a family of tropical plants from Anacardiaceae originating from Brazil that also grows in the Indian and African regions [8]. Previous research shows that cashew apple can reduce blood sugar $[9,10]$. Cashew apple contains flavonoids namely anthocyanin and 13 glycosylated flavonols [11]. Flavonoid plays a role in the medical treatment of Diabetes Mellitus because it is compound components which demonstrate synergy effect on $\alpha$-glucosidase enzyme inhibitory activity [12].

Based on the explanation above, this research was conducted to observe the combination of cashew apple extracts and brotowali stem which may have a synergistic effect on the inhibition of $\alpha$ glucosidase as antidiabetic.

\section{MATERIALS AND METHOD}

\section{Materials}

Analytical scales (Ohaus), rotary evaporator (Heidolph), water bath (Mammert), micropipette (Scorex), vortex (Vortex Maxi Mix II 37600), incubator (Mammert), Elisa reader (BIOTEK Elx 800), 96- well microplate (Iwaki), and glassware (Pyrex), pH Meter.

Cashew apple (Anacardium occidentale L.), brotowali stem (Tinospora cordifolia), 96\% ethanol, $\alpha$-glucosidase enzyme (Sigma Aldrich, USA), aqua pro injection, phosphate buffer, p-nitrophenyl$\alpha$-D-glucopyranoside (Sigma Aldrich, USA), p-nitrophenol, bovine albumin serum (Sigma Aldrich, USA), $\mathrm{Na}_{2} \mathrm{CO}_{3}$ (Merck), DMSO (Merck), NaCl (Merck), $1 \mathrm{M} \mathrm{NaOH}, 0.5 \% \mathrm{NaSO}_{3}, 50 \mathrm{mM}$ sodium dihydrogen phosphate $\left(\mathrm{NaH}_{2} \mathrm{PO}_{4}\right), 50 \mathrm{mM}$ disodium hydrogen phosphate $\left(\mathrm{Na}_{2} \mathrm{HPO}_{4} \cdot \mathrm{H}_{2} \mathrm{O}\right)$.

\section{The Production of $96 \%$ Ethanolic Extract of Brotowali Stem and Cashew Apple}

Brotowali stem and cashew apple powders were weighed $200 \mathrm{mg}$ each. Then, each powder was macerated with 1.5 liters of $96 \%$ ethanol for three days and was occasionally stirred. The immersion result was then filtered by using a Buchner funnel, and the filtrate was evaporated using rotatory evaporator at $60{ }^{\circ} \mathrm{C}$. The extract was thickened on the water bath until the extract was thick.

\section{The Production of Combination of Ethanolic Extract of Brotowali Stem and Cashew Apple}

5\% cashew apple stock solution and brotowali were diluted ten times using DMSO that each extract had a concentration of $0.5 \%$. From that $0.5 \%$ concentration extract, some volumes with various comparisons were taken as shown in Table 1. 


\section{The Making of p-Nitrophenol Standard Curve \\ P-nitrophenol 13,911 $\mathrm{mg}$ was} dissolved into phosphate buffer with $\mathrm{pH}$ 6.9 to $10 \mathrm{~mL}$; then it was diluted to obtain a series of concentrations of $0,10,20,40$, 80,160 , and 320 in a $\mathrm{pH}$ phosphate buffer solution. Then absorbance was measured at $405 \mathrm{~nm}$ using ELISA Reader.

\section{Activity Test for $\alpha$-glucosidase Enzyme Inhibition}

This activity test for $\alpha$-glucosidase Enzyme Inhibition used the spectrophotometric method with ELISA reader instrument. The enzyme used was an $\alpha$-glucosidase enzyme with a concentration of 0.05 units $/ \mathrm{mL}$ and the substrate used was p-nitrophenyl- $\alpha-D$ glucopyranoside (p-NPG) with a concentration of $20 \mathrm{mM}$.

Cashew apple and brotowali stem extracts were dissolved in DMSO with different concentration series, namely $0.025 ; 0.05 ; 0.1 ; 0.2 ; 0.4$ for Brotowali and $0.25 ; 0.5 ; 1 ; 2 ; 4$ in \%b/v unit for Cashew Apple. The reaction between the enzyme and the substrate was stopped by $\mathrm{Na}_{2} \mathrm{CO}_{3}$. The absorbance was read by ELISA Reader at a wavelength of $405 \mathrm{~nm}$. Five combinations of brotowali stem and cashew apple were tested with a reaction system between the enzyme and the substrate which was stopped by $\mathrm{Na}_{2} \mathrm{CO}_{3}$. The absorbance was read by the ELISA Reader at a wavelength of $405 \mathrm{~nm}$.

Table 1. Combination of Cashew Apple and Brotowali Extracts

\begin{tabular}{cccc}
\hline Combination & $\begin{array}{c}\text { Comparison of Brotowali: } \\
\text { Cashew Apple }\end{array}$ & $\begin{array}{c}\text { Brotowali Extract } \\
\text { Solution Taking }(\mathrm{mL})\end{array}$ & $\begin{array}{c}\text { Cashew Apple Extract } \\
\text { Solution Taking }(\mathrm{mL})\end{array}$ \\
\hline 1 & $1: 0$ & 0,5 & 0 \\
2 & $1: 2$ & 0,5 & 1 \\
3 & $1: 1$ & 0,5 & 0,5 \\
4 & $2: 1$ & 1 & 0,5 \\
5 & $0: 1$ & 0 & 0,5 \\
\hline
\end{tabular}

Table 2. Reaction system of $\alpha$ glucosidase inhibition

\begin{tabular}{lllll}
\hline Solutions & Blank & $\mathrm{C}$ & $\mathrm{S}_{0}$ & $\mathrm{~S}_{1}$ \\
\hline Sample $($ Extract $)(\mu \mathrm{L})$ & - & - & 1 & 1 \\
DMSO $(\mu \mathrm{L})$ & 1 & 1 & - & - \\
Buffer $(\mu \mathrm{L})$ & 49 & 49 & 49 & 49 \\
Substrate $(\mu \mathrm{L})$ & 25 & 25 & 25 & 25 \\
& Incubated at & $37^{\circ} \mathrm{C}$ for 5 minutes \\
Buffer $(\mu \mathrm{L})$ & 25 & - & 25 & - \\
Enzyme $(\mu \mathrm{L})$ & - & 25 & - & 25 \\
& Incubated at & $37^{\circ} \mathrm{C}$ for 15 minutes & \\
$\mathrm{Na}_{2} \mathrm{CO}_{3}(\mu \mathrm{L})$ & 100 & 100 & 100 & 100
\end{tabular}

Information:

Blank $=$ Reaction system without extract and enzyme

$\mathrm{C}=$ Negative control (reaction of substrate and enzyme)

$\mathrm{S}_{\mathrm{o}} \quad=$ Mixture which contains extract without enzyme

$\mathrm{S}_{1} \quad=$ Mixture which contains extract and enzyme 


\section{Analysis Data}

The linear regression equation for each extract sample was used to calculate $\mathrm{IC}_{50}$ of each extract with the $\mathrm{x}$-axis as the concentration of each sample and the yaxis as a percentage (\%) of inhibition. Based on the equation of $y=a+b x, I_{50}$ value can be calculated. Data from the combination of the cashew-brotowali extract obtained was analyzed quantitatively with one-factor ANOVA.

\section{RESULTS AND DISCUSSION}

\section{6\% Ethanolic Extraction of Brotowali Stem and Cashew Apple}

The extraction method used was maceration, which is an extraction method by immersing the material in a solvent [13]. A maceration is an option because this method is simple, easy to do, can extract in large quantities, produce good yields, and not getting any physical disturbances [13, 14]. The solvent used was $96 \%$ ethanol, ethanol is the main choice of solvent to extract secondary metabolites whose structure is unknown [13]. The brotowali condensed extract obtained is 7.74 grams with a yield of $8.147 \%$, while cashew apple condensed extract obtained is 161.151 grams with a yield of $80.575 \%$

\section{p-nitrophenol Standard Curve}

The value of the standard curve was obtained from the graph of the relationship between absorbance and concentration. The value of p-Nitrofenol (p-NP) standard curve obtained is a straight line of $\mathrm{y}=$ $0.00386 x+0.06569$ with a value of $\mathrm{R} 2=$ 0.999 . A value of $R^{2}=1$ which means that the increase in absorbance of p-nitrophenol is directly proportional to the increase in $\mathrm{p}$ nitrophenol concentration. Extract samples were used as enzyme inhibitors because their activities as inhibitors will affect the enzyme bond with the substrate so that the bonds become small in number. This made the p-nitrophenol formed became few so that the absorbance value became small as the concentration of the extract increased. The reading of $\mathrm{p}$-NP standard curve was carried out at a wavelength of $405 \mathrm{~nm}$ because the yellowish p-NP compound has a wavelength area of about $405 \mathrm{~nm}$ [15].

\section{Activity Test for Single Extract of $\alpha$ - Glucosidase Enzyme Inhibition}

The test results of $\alpha$-Glucosidase inhibitory activity were obtained from the reading of absorbance using ELISA reader at a wavelength of $405 \mathrm{~nm}$; this absorbance reading illustrated the levels of $p$ Nitrofenol ( $\mathrm{p}-\mathrm{NP})$ products formed. The absorbance measured is directly proportional to the p-NP product formed. The higher the sample's concentration, the lower the absorbance measured and the higher the inhibitory power of the $\alpha$ Glucosidase enzyme. The measured absorbance is directly proportional to the number of living cells.

In the inhibitory activity test of the $\alpha$-glucosidase enzyme, the $\mathrm{IC}_{50}$ values obtained from each extract were as follows: $96 \%$ ethanolic extract of brotowali stem of $34.61 \mu \mathrm{g} / \mathrm{mL}$ and cashew fruit of 109.32 $\mu \mathrm{g} / \mathrm{mL} . \quad \mathrm{IC}_{50}$ is the concentration value which shows the inhibition of $\alpha$ glucosidase enzyme of $50 \%$. $\mathrm{IC}_{50}$ values indicate the potential of a compound as an $\alpha$-glucosidase enzyme inhibitor: the greater the $\mathrm{IC}_{50}$ value, the less potent the compound as an $\alpha$-glucosidase enzyme inhibitor.

A sample which has $\alpha$-glucosidase enzyme inhibitory activity is stated as follows, (1) $\mathrm{IC}_{50} \leq 25 \mu \mathrm{g} / \mathrm{mL}$ is categorized as very active, (2) The value of $\mathrm{IC}_{50}=25$ $<\mathrm{IC}_{50} \leq 50$ is categorized as active, (3) it is categorized as less active if $50<\mathrm{IC}_{50} \leq 100$, and (4) The value of $\mathrm{IC}_{50}>100 \mu \mathrm{g} / \mathrm{mL}$ is categorized as $[16,17]$. The results show that the Brotowali Stem extract is potential as an $\alpha$-glucosidase inhibitor, while cashew apple extract is not potential as an $\alpha$ glucosidase inhibitor. 
$\alpha$-Glucosidase Inhibitory Activity of In Vitro Combination of 96\% Ethanolic Extract of Brotowali Stem (Tinospora cordifolia) and Cashew Apple (Anacardium occidentale L.)

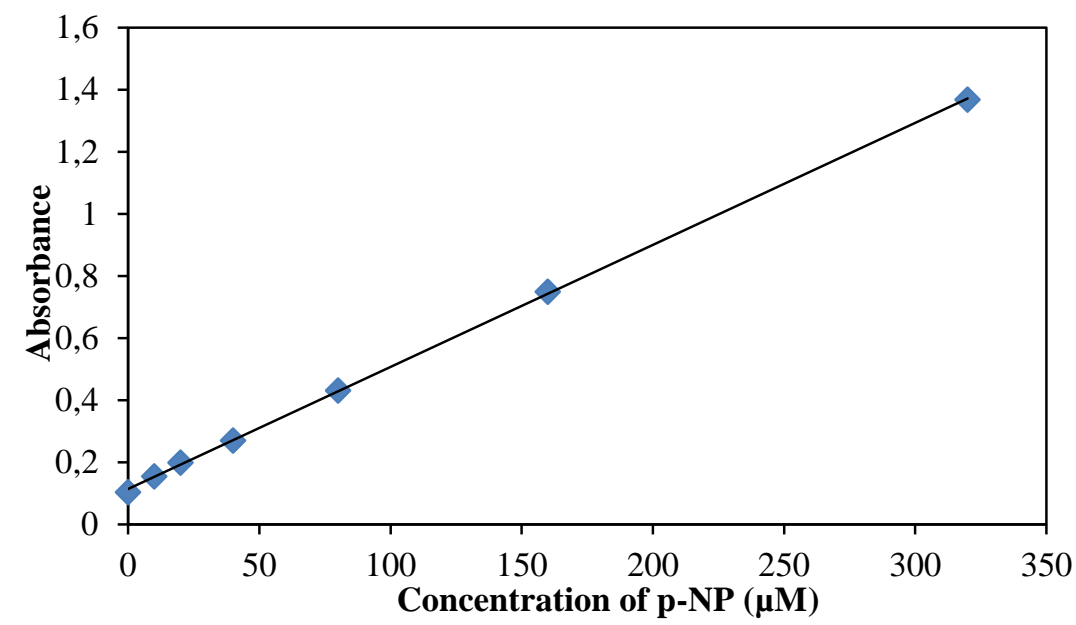

Figure 1. p-Nitrofenol (p-NP) Standard Curve

Table 3. The $\mathrm{IC}_{50}$ Results of $96 \%$ ethanolic Extract of Brotowali Stem and Cashew Apple

\begin{tabular}{ccc}
\hline Sample $(\mu \mathrm{g} / \mathrm{mL})$ & Inhibitory Power Mean $(\%)$ & $\mathrm{IC}_{50}(\mu \mathrm{g} / \mathrm{mL})$ \\
\hline Brotowali & & 34.61 \\
\hline 1.25 & $25.896 \pm 0.39$ & \\
2.5 & $36.74 \pm 3.1$ & \\
5 & $42.163 \pm 0.09$ & \\
20 & $44.874 \pm 1.1$ & \\
Cashew Apple & $68.822 \pm 1.53$ & 109.32 \\
\hline 125 & & \\
25 & $25.896 \pm 2.0$ & \\
50 & $36.74 \pm 1.33$ & \\
100 & $42.163 \pm 1.33$ & \\
200 & $44.874 \pm 1.33$ & \\
\hline
\end{tabular}

Table 4. The Percentage Results of $\alpha$-Glucosidase Enzyme Inhibitory Power of Brotowali Stem and Cashew Apple Combination

\begin{tabular}{cc}
\hline Combination & \% Inhibitory Power Mean \\
\hline 1 & $84.05 \pm 5.85$ \\
2 & $69.581 \pm 0.67$ \\
3 & $70.927 \pm 1.08$ \\
4 & $68.101 \pm 2.59$ \\
5 & $40.374 \pm 6.08$ \\
\hline
\end{tabular}

Table 5. Single-Factor ANOVA test for Percentage of $\alpha$-Glucosidase Enzyme Inhibitory Power

\begin{tabular}{ccc}
\hline & $\begin{array}{c}\text { Combination of Cashew Apple } \\
\text { and Brotowali }\end{array}$ & $\begin{array}{c}\text { Combination 2, 3, and 4 of Brotowali } \\
\text { Stem and Cashew Apple }\end{array}$ \\
\hline F count & 32.88421 & 1.440992 \\
F table & 3.47805 & 5.143253 \\
Information & F count $>$ F table & F count $<$ F table \\
\hline
\end{tabular}




\section{Activity Test for Combination Extract of Brotowali Stem and Cashew Apple}

The brotowali-cashew extract combination with the comparison as shown in Table 1, was analyzed by ANOVA with a level of $5 \%$. The results obtained on the $\%$ inhibition of the $\alpha$-glucosidase enzyme by brotowali-cashew apple are shown in Table 4. In the test of $\alpha$-glucosidase enzyme activity, $\mathrm{F}$ count $>\mathrm{F}$ table at the level of 5\% means that the difference in the combination of brotowali stem and cashew apple influence the \% Enzyme Inhibitory Power. Combinations of 2, 3 , and 4 have a mean percentage of inhibitory power that is almost similar, after testing the three combinations of ANOVA, the results are obtained that $\mathrm{F}$ count $<\mathrm{F}$ table, at the level of $5 \%$ with a value of $1.440992<5.143253$ (Table 5. ) F count $<F$ table at the level of $5 \%$ means that there is no significant effect between the differences in the combination of brotowali stem and cashew apple combination of 2, 3, and four towards the $\%$ of $\alpha$-Glucosidase Enzyme Inhibitory Power. This means that there is no significant effect between the differences in the combination of Brotowali stem and cashew apple towards the \% of enzyme inhibitory power.

Combination 1 is a single extract of Brotowali, while combination 5 is a single extract of the cashew apple. The results of the research demonstrate that single extract of brotowali has the highest percentage of inhibitory power compared to the combination 2, 3, 4 and the single extract of the cashew apple, while cashew apple has the lowest percentage of inhibitory power among the other samples. The other three combinations have a smaller percentage of inhibitory power compared to Brotowali single extract, but it has bigger percentage of inhibitory power than the single extract of cashew apple has. From this results, it shows that extract combination does not give synergic effect. Therefore, the use of a combination of brotowali-cashew apple extract is not as effective as the use of brotowali single extracts to inhibit the $\alpha$-glucosidase enzyme.

\section{CONCLUSION}

$96 \%$ ethanolic extract of the combination of brotowali and cashew apple has $\alpha$-glucosidase enzyme inhibitory activity. Analysis result demonstrates that there was significant influence between every combination of brotowali and cashew apple. $\mathrm{IC}_{50}$ is obtained at every single sample namely $\mathrm{IC}_{50}$ of brotowali, and cashew apple are $109.32 \mu \mathrm{g} / \mathrm{ml}$ and $34.61 \mu \mathrm{g} / \mathrm{mL}$ for $\alpha$ glucosidase enzyme inhibitory activity. From the analysis results, $\alpha$-glucosidase enzyme inhibitory activity shows that the extract combination does not give synergic effect. Therefore, the use of an extract of brotowali-cashew apple extract is not as effective as the use of the extract of the single brotowali stem in inhibiting the $\alpha$ glucosidase enzyme.

\section{ACKNOWLEDGMENT}

We would like to express our thanks of gratitude to the laboratory assistants at the laboratory of Faculty of Pharmacy, Muhammadiyah University of Surakarta for giving assistance, guidance and instructions in the technical implementation.

\section{REFERENCES}

[1] Organization, W. H., 2016. Global report on diabetes. World Health Organization.

[2] Kalra, S., 2014. Alpha glucosidase inhibitors. JPMA. The Journal of the Pakistan Medical Association. 64. 474-476.

[3] Kwon, Y.-I., Apostolidis, E., Shetty, K., 2008. In vitro studies of eggplant (Solanum melongena) phenolics as inhibitors of key enzymes relevant for type 2 diabetes and hypertension. 
Bioresource Technology. 99. 29812988.

[4] Campbell, L. K., Baker, D. E., Campbell, R. K., 2000. Miglitol: assessment of its role in the treatment of patients with diabetes mellitus. Annals of Pharmacotherapy. 34. 1291-1301.

[5] Patel, M. B., Mishra, S., 2011. Hypoglycemic activity of alkaloidal fraction of Tinospora cordifolia. Phytomedicine. 18. 1045-1052.

[6] Chougale, A. D., Ghadyale, V. A., Panaskar, S. N., Arvindekar, A. U., 2009. Alpha glucosidase inhibition by stem extract of Tinospora cordifolia. Journal of Enzyme Inhibition and Medicinal Chemistry. 24. 998-1001.

[7] Hamid, H., Yusoff, M., Liu, M., Karim, M., 2015. $\alpha$-Glucosidase and $\alpha$-amylase inhibitory constituents of Tinospora crispa: Isolation and chemical profile confirmation by ultra-high performance liquid chromatography-quadrupole timeof-flight/mass spectrometry. Journal of Functional Foods. 16. 74-80.

[8] Trevisan, M., Pfundstein, B., Haubner, R., Würtele, G., Spiegelhalder, B., Bartsch, H., Owen, R., 2006. Characterization of alkyl phenols in cashew (Anacardium occidentale) products and assay of their antioxidant capacity. Food and Chemical Toxicology. 44. 188-197.

[9] Alexander - Lindo, R. L., Morrison, E. S. A., Nair, M. G., 2004. Hypoglycaemic effect of stigmast - 4 - en - 3 - one and its corresponding alcohol from the bark of Anacardium occidentale (cashew). Phytotherapy Research: An International Journal Devoted to Pharmacological and Toxicological Evaluation of Natural Product Derivatives. 18. 403-407.

[10] Esimone, C., Okonta, J., Ezugwu, C., 2001. Blood sugar lowering effect of Anacardium occidentale leaf extract in experimental rabbit model. Journal of Natural Remedies. 1. 60-63.

[11] de Brito, E. S., de Araújo, M. C. P., Lin, L.-Z., Harnly, J., 2007. Determination of the flavonoid components of cashew apple (Anacardium occidentale) by LCDAD-ESI/MS. Food chemistry. 105. 1112-1118.

[12] Wang, H., Du, Y.-J., Song, H.-C., 2010. $\alpha$-Glucosidase and $\alpha$ amylase inhibitory activities of guava leaves. Food chemistry. 123. 6-13.

[13] Saifudin, A., 2014. Senyawa alam metabolit sekunder: Teori, konsep, dan teknik pemurnian. Deepublish.

[14] Indonesia, D. K. R., 2000. Parameter standar umum ekstrak tumbuhan obat. Jakarta: Departemen Kesehatan Republik Indonesia. 9-12.

[15] Gandjar, I. G., Rohman, A., 2007. Kimia farmasi analisis. Pustaka Pelajar, Yogyakarta. 299. 463-480.

[16] Sabu, M., Smitha, K., Kuttan, R., 2002. Anti-diabetic activity of green tea polyphenols and their role in reducing oxidative stress in experimental diabetes. Journal of ethnopharmacology. 83. 109-116.

[17] Kim, Y.-M., Jeong, Y.-K., Wang, M.-H., Lee, W.-Y., Rhee, H.-I., 2005. Inhibitory effect of pine extract on $\alpha$-glucosidase activity and postprandial hyperglycemia. Nutrition. 21. 756-761. 